Volume 7 No. 1, Juni 2020

P-ISSN: 2406-808X // E-ISSN: 2550-0686

https://journal.iainlangsa.ac.id/index.php/ikhtibar

https://doi.org/10.32505/ikhtibar.v7il.612

\title{
PENDIDIKAN KARAKTER PERSPEKTIF IBNU SINA
}

\author{
Hambali Alman Nasution \\ UIN Sunan Kalijaga \\ fikrialwi19@gmail.com
}

\begin{abstract}
Abstrak
Tujuan dalam penelitian ini adalah untuk mengetahui bagaimana pendidikan perspektif Ibnu Sina dalam pendidikan karakter, pemikiran pendidikan menurut Ibnu Sina bertujuan bahwa pendidikan tidak hanya transfer pengetahuan saja, tetapi disertai dengan transfer nilai. Dalam penenelitian ini menggunakan jenis penelitian kepustakaan. Pengumpulan data dengan menggunakan dokumentasi. Analisis data menggunakan metode dekriptif kualitatif, dengan menggunakan penelitian literatur. Hasil penelitian yang diperoleh Ibnu Sina ia mengungkapkan bahwa karakter manusia tumbuh dan berkembang bila bagaimana kita memberikan pendidikan yang sesuai dengan potensi-potensi peserta didik. Ibnu sina memandang bahwa pendidikan sebagai sarana untuk menjadikan peserta didik mulia dan berbudi pekerti luhur bukan hanya sekedar pada pengetahuanya.
\end{abstract}

Kata Kunci: Pendidikan, Karakter, Perspektif Ibnu Sina

\section{Pendahuluan}

Kehidupan dalam era global yang pesat menuntut berbagai perubahan, baik itu perubahan dalam pendidikan secara mendasar. Adapun perubahan tersebut meliputi: perubahan dari pandangan kehidupan masyarakat lokal ke masyarakat global, perubahan kohesi sosial menjadi partisipasi demokratis dan perubahan dari pertumbuhan ekonomi ke perkembangan kemanusiaan. ${ }^{1}$

Dalam menghadapi berbagai perubahan dan perkembangan masalah diatas, pentingnya untuk melakukan penataan terhadap sistem pendidikan secarah utuh dan menyeluruh, terutama berkaitan dengan kualitas pendidikan, serta relevansinya dengan kebutuhan masyarakat dan perkembangan zaman. Dalam hal ini, perlu adanya perubahan sosial yang memberi arah bahwa pendidikan merupakan pendekatan dasar dalam proses perubahan itu. Dalam pendidikan belajar merupakan proses memanusiakan manusia, dimana hanya melalui belajar manusia menemukan dirinya dalam relasinya dengan sang pencipta. Melalui

${ }^{1}$ Prof. Mulyasa, Pengembangan dan Implementasi Kurikulum 2013 (Bandung: PT. Remaja Rosdakarya, 2013), hal. 2. 
belajar manusia mengaktualisasikan diri dan lingkunganya sedemikian sehingga kualitas hidup dan penghidupan menjadi baik dan bermanfaat. ${ }^{2}$

Sehubungan dengan Undang-Undang Nomor 20 Tahun 2003 tentang Sistem Pendidikan Nasional, pendidikan adalah usaha sadar dan terencana untuk mewujudkan suasana belajar dan proses pembelajaran agar peserta didik secara aktif mengembangkan potensi dirinya untuk memiliki kekuatan spiritual keagamaan, pengendalian diri, kepribadian, kecerdasan, akhlak mulia, serta keterampilan yang diperlukan dirinya, masyarakat, bangsa dan Negara. $^{3}$ Pendidikan sebagai nilai universal kehidupan memiliki tujuan yang disepakati setiap kawasan dan pada setiap zaman serta dalam semua pikiran. Dengan bahasa sederhana, tujuan yang disepakati itu adalah mengubah manusia menjadi lebih baik dalam sikap, pengetahuan dan keterampilan. ${ }^{4}$

Sedangkan dalam pendidikan agama Islam bimbingan jasmani dan rohani berdasarkan hukum-hukum agama Islam menuju kepada terbentuknya kepribadian utama menurut ukuran-ukuran Islam. ${ }^{5}$ Sedangkan menurut zakiah Darajat, pendidikan agama Islam adalah pendidikan yang diajarkan berdasarkan syariat Islam, yaitu berupa bimbingan dan asuhan terhadap anak didik agar nantinya setelah selesai dari pendidikan ia dapat memahami, menghayati dan mengamalkan ajaran-ajaran agama Islam yang telah diyakini secara menyeluruh, serta menjadikan ajaran Islam itu sebagai suatu pandangan hidupnya demi keselamatan dan kesejahteraan dunia dan di akhirat kelak. ${ }^{6}$

Pendidikan umat Islam berusaha mengarahkan peserta didik memiliki etika sesuai dengan ajaran Islam, dengan begitu peserta didik akan dapat mengembangkan segala potensi yang ada pada dirinya untuk kemaslahatan kehidupan seluruh umat manusia. ${ }^{7}$

Karakter merupakan suatu keadaan jiwa seseorang. Keadaan ini merupakan jiwa bertindak tanpa mempertimbangkan secara mendalam. Keadaan seperti ini terdiri dari dua jenis yakni, alamiah dan terciptanya melalui kebiasaan dan latihan. Pada dasarnya kejadian ini bermula karena dipertimbangkan dan dipikirkan, dengan demikian dilakukan terus menerus sehingga menjadi karakter. ${ }^{8}$ Pendidikan karakter bertujuan membina terbentuknya perilaku yang baik bagi setiap orang. Artinya pendidikan karakter bukan sekedar memahami tentang

${ }^{2}$ Slameto, Proses Belajar Mengajar Dalam Sistem Kredit Smester (Jakarta: Bumi Aksara, 1991), hal. 5.

${ }^{3}$ Ramayulis, Ilmu Pendidikan Islam (Jakarta: Kalam Mulia, 2002), 13.

${ }^{4}$ Abdul Majid, Dian Andayani, Pendidikan Karakter Perspektif Islam (Bandung: PT. Remaja Rosdakarya, 2017), 4.

${ }^{5}$ Armai Arief, Pengantar Ilmu dan Metodologi Pendidikan Islam (Jakarta: Ciputat pers, 2002), 4.

${ }^{6}$ Zakiah Drajat dkk, Ilmu Pendidikan Islam (Jakarta: Bumi Aksara, 2012), 86. 2015), 10.

${ }^{7}$ Sutrisno dan Suyatno, Pendidikan Islam Di Era Peradaban Modern (Jakarta: Kencana,

${ }^{8}$ Ibn Miskawaih, Menuju Kesempurnaan Akhlak Terjemahan dari Tahdjib Al-Akhlak Karya Abu Ali Ahmad Ibn Miskawaih (Bandung: Mizan, 1994), hal. 56. 
aturan benar atau salah atau mengetahui ketentuan baik dan buruk, akan tetapi harus benar-benar meningkatkan karakter perilaku seseorang. Oleh sebab itu, evaluasi keberhasilanya harus menggunakan pengaplikasian tingkahlaku sebagai tolak ukurnya. ${ }^{9}$

Problem penyimpangan atau kemorosatan moral pada saat ini menjangkit sebagian generasi muda. Gejala kemresotoan moral antara lain dikarena merebaknya kasus penyalahgunaan narkoba, pornografi, tawuran pelajar, penipuan, pencurian, bulliying, perjudian, pelacuran dan pembunuhan serta bebrapa perilaku penyimpangan sosial yang tidak terpuji. Disis lain, sebagian besar generasi muda gagal untuk untuk mengaktualisasikan perilaku terpuji (Akhlak) sesuai dengan harapan orang tua dan syariat Islam. Kehormatan, kesopanan, sifat ramah rendah diri, tenggang rasa, saling tolong menolong dalam kebaikan dan kebenaran, gotong royong dan solidaritas sosial dan sebagainya yang merupakan jati diri bangsa seolah-olah kurang begitu melekat didalam diri mereka. ${ }^{10}$

Dekadensi moral pada kalangan anak sangat begitu meperihatinkan, ini merupakan tamparan keras bagi kita semua. Hal ini dipengaruhi oleh perkembangan dan pergaulan zaman yang terus berkembang dan cendrung pada pergaulan bebas sehingga mereka berbuat sesuai kehendaknya, ini terus erjadi padahal pendidikan diberikan pada anak. Dari penjelasan diatas terkait pendidikan karakter, dalam artikel ini peneliti berusaha untuk fokus pada karakter atau moral anak dan dampak yang ditimbulkan anak dalam endidikan Islam. Untuk berkaitan dengan pendidikan karakter atau moral, penulis menggunakan pemikiran Ibnu Sina sebagai acuan untuk menganalisis permasalahan tersebut.

\section{Metode Penelitian}

Adapun metode yang digunakan dalam penelitian ini adalah analisis deskriptif kualitatif. Analisisis deskriptif kualitatif merupakan cara analisis yang cenderung menggunakan kata-kata untuk menggambarkan dan menjelaskan data atau fenomena yang telah diperoleh.

Adapun jenis penelitian yang digunakan adalah penelitian kepustakaan (library reserch) penelitian yang digunakan untuk memecahkan suatu problem yang bersifat konseptual teoritis, baik tentang tokoh pendidikan ataupun konsep pendidikan tertentu seperti tujuan, metode, teknik dan lingkungan pendidikan. ${ }^{11}$ Secara sederhana penelitian kepustakaan adalah jenis penelitian yang berusaha mengimpundata dari berbagai literatur dan menjadikan sebagai objek utama

\footnotetext{
${ }^{9}$ Syarkawi, Pembentukan Kepribadian Anak (Jakarta: Bumi Aksara, 2011), hal. 38.

${ }^{10}$ Syarnubi Syarnubi, "PROFESIONALISME GURU PENDIDIKAN AGAMA ISLAM DALAM MEMBENTUK RELIGIUSITAS SISWA KELAS IV DI SDN 2 PENGARAYAN," Tadrib 5, no. 1 (1 Juli 2019): 87-103, https://doi.org/10.19109/tadrib.v5i1.3230.

11 Suwardi dkk, Panduan Penulisan Skripsi (Yogyakarta: FITK UIN Sunan Kalijaga, 2012) hal 20.
} 
analisisnya. ${ }^{12}$ Dalam penelitian ini, penulis ingin meneliti dan menganalisis pengembangan teknik dan instrumen asesmen aspek pengetahuan berbasis teknologi.

Penulis mengumpukan data dengan cara dokumentasi. Dokumentasi atau studi dokumenter (documentary study) merupakan suatu teknik pengumpulan data dengan menghimpun dan menganalisis dokumen-dokumen, baik dokumen tertlis, gambar maupun elektronik. ${ }^{13}$ Nuku-buku, jurnal-jurnal dan sumber internet yang digunakan dalam penelitian ini bertujuan untuk memperoleh data mengenai pengembangan teknik dan instrumen asesmen aspek pengetahuan berbasis teknologi.

\section{Hasil dan Pembahasan}

\section{A. Konsep Dasar Pendidikan Pemikiran Ibnu Sina di Era Modern}

Dalam pendidikan Pemikiran Ibnu Sina mencakup unsur penting dalam pendidikan. Di antaranya ialah tujuan pendidikan Islam, kurikulum pendidikan Islam, metode pembelajaran yang efektif, kriteria guru yang ideal, dan konsep hukuman edukatif, adapun penjelasan lengkapnya ialah sebagai berikut: ${ }^{14}$

\section{Tujuan Pendidikan Islam}

Ibnu Sina berpendapat bahwa tujuan pendidikan Islam mesti diarahkan pada pengembangan seluruh potensi murid, baik potensi itu ibtlektual, fisik, maupun budi pekerti. Selain itu, tujuan Pendidikan Islam mesti pula dimaksudkan untuk mempersiapakan murid agar mampu hidup bermasyarakat dan memilki pekerjaan, serta keahlian tertentu yang sesuai dengan bakat atau potensinya.

Ibu Sina menyatakan bahwa hendaknya tujuan pendidikan tidak melupakan pembinaan fisik murid. Sebab, pembinaan fisik, seperti memberikan pendidikan olahraga dan pola makan yang sehat, dimaksudkan agar murid memiliki pertumbuhan fisik yang paripurna. Bahkan pembinaan fisik juga dipercaya dapat berpengaruh positif terhadap kecerdasan otak murid.

Sementara itu, untuk mengembangkan potensi intelektual murid, Ibnu Sina menyarankan beberapa hal. Di antaranya, selain dengan olahraga dan pola makan yang baik, iaalah dengan memberikan pendidikan kesenian. Pendidikan kesenian diyakini akan mampu meningkatkan daya kreativitas dan daya khayal sehingga mampu tempil sebagai manusia yang kreatif dan inovatif.

Selanjutnya, melalui pendidikan budi pekerti diharapakan murid memilki ragam kebiasaan yang positif, seperti bersikap sopan dan santun dalam pergaulan hidup sehari-hari. Dan tujuan utamanya ialah untuk mencapai kebahagiaan sejati. Sebab, hanya dengan pembentukan budi pekerti atau akhlak yang mulia, murid

\section{${ }^{12}$ Suwardi dkk,}

${ }^{13}$ Nana Syaodih Sukmadhinata, Metode Penelitian Pendidikan (Bandung: PT. Remaja Rosdakarya, 2012).

${ }^{14}$ Sirajuddin Zar, Filsafat Islam filosof dan filsafatnya (Jakarta: PT. Raja Grafindo Parsada, 2012), hal. 91-92. 
akan meraih kebahagiaan yang sejati sebagai makhluk yang diciptakan oleh Allah swt. Dihubungkan antara satu dengan yang lainnya, maka akan tampak jelas bahwa penadapat Ibnu Sina tersebut bersifat hierarkis struktural. Maksudnya, Ibnu Sina memiliki pendapat tentang tujuan pendidikan yang bersifat universal dan bersifat kutukuler atau tiap bidang studi, serta tujuan yang bersifat operasional.

Tujuan pendidikan Ibnu Sina tersebut tampak didasarkan pada pamdagannya mengenai insan kamil (manusia yang sempurna). Arti dari manusia sempurna ialah manusia yang terbina seluruh potensi dirinya secara seimbang dan meneyeluruh. Ibnu Sina tampak ingin agar tujuan pendidikan universal itu diarahkan kepada terbentuknya manusia yang sempurna.

\section{Kurikulum Pendidikan Islam}

Pemikiran Ibnu sina tentang kurikulum pendidikan Islam, ia dasarkan pada tingkat perkembangan usia murid. Dalam hal ini, ada tiga klasifikasi murid berdasarkan perkembangan usianya yaitu $:^{15}$

\section{a. Usia 3-5 tahun}

Pendidikan pada usia tiga sampai lima tahun dapat disebut sebagai pendidikan usia dini. Menurut Ibnu Sina, anak atau murid usia tiga sampai lima tahun, amatlah perlu diberikan mata pelajaran olahraga, budi pekerti, kebersihan, seni suara, dan kesenian. setiap mata pelajaran ini memiliki tujuan tersendiri. Oleh sebab itu, penyelnggara pendidikan, dalam hal ini ialah guru, mesti memberikan porsi yang pas.

Mata pelajaran olahraga bertujuan untuk membina kesempurnaan pertumbuhan fisik si anak secara optimal. Oleh sebab itu, pelajaran olahraga harus disesuakan dengan tingkat perkembangan anak, serta bakat yang dimilikinya. Jangan sampai guru memberikan porsi olahraga yang berlebihan pada murid pada usia 3-5 tahun. sebab, porsi yang tidak tepat hanya akan membahayakan keselamatan murid.

Kemudian mata pelajaran budi pekerti diarahkan untuk membekali si anak agar memiliki kebiasaan atau sikap yang positif, seperti mampu bersikap sopan dan santun dalam pergaulan hidup sehari-hari. Pelajaran ini tentunya amat dibutuhkan agar murid memiliki kepribadian yang luhur sejak usia belia. Alhasil, pada masa mendatang, ia tidak akan melakukan berbagai tindakan tercela.

Mengenai pelajaran kebersihan, Ibnu Sina mengatakan bawha pelajaran hidup bersih dimulai dari sejak anak bangun tidur,ketika hendak makan, sampai ketika hendak tidur kembali. Dengan cara demikian, dapat diketahui murid yang telah mampu menerapkan hidup sehat dan bersih, serta murid yang berpenampilan kotor dan kurang sehat, serta diajarkannya mata pelajaran kesenian dan seni suara bertujuan agar murid memiliki ketjaman perasaan dalam mencintai dan meningkatkan daya khayalnya. Alhasil, murid dapat menjadi manusia yang

${ }^{15}$ Yanuar Arifin, Pemikiran-Pemikiran Emas Para Tokoh Pendidikan Islam dari Klasik hingga Modern (Yogyakarta: Lintang Pusataka Utama, 2017), hal. 57. 
kraeatif. Selain itu,juga dimaksudkan untuk memperhalus budi pekerti yang pada gilirannya akan melahirkan kecintaan terhadap keindahan.

\section{b. Usia 6-14 Tahun}

Menurut Ibnu Sina, kurikulum untuk usia enam sampai empat belas tahun memahami pelajaran membaca dan menghafal Al-Qur'an, pelajaran agama, pelajaran syair, serta pelajaran kesehatan jasmani. Pelajaran-pelajaran ini memiliki banyak keutamaan bagi murid sehingga amat penting untuk oleh penyelenggara pendidikan atau guru.

Perlu diketahui, pelajaran membaca dan menghafal al-Qur'an bertujuan untuk mendukung pelaksanaan ibadah yang memerlukan bacaan ayat-ayat alQur'an, seperti dalam pelaksanaan ibadah shalat, dan pelajaran ini juga mengandung peran yang efektif dalam keberhasilan dalam belajar, seperti dalam pembelajaran tafsir Al-Qur'an, tauhid, akhlak, fiqih dan beberapa pembelajaran agama lainnya yang menjadikan Al-Qur'an sebagai sumber utamanya. Dalam pembelajaran membaca dan menghafal al-Qur'an bermanfat untuk mendukung kesuksesan murid dalam mempelajari bahasa Arab. Sebab, dengan menguasai alQur'an sama artinya murid memguasai ribuan kosa kata bahasa arab. Oleh sebab itu, pelajaran membaca al-Qur'an amatlah penting dalam melahirkan generasi muslim yang mumpumi dalam bidamg keilmuwan Islam.

pada usia dini sebagai lanjutan dari pelajaran seni pada tingkat sebelumnya. Murid diharapkan mampu menghafal beberapa syair yang tekandung nilai-nilai pendidikan dalam menuntun perilakunya. Alhasil, dengan baiknya perilaku, ia akan menjadi bagian dari generasi muslim yang berprestasi dan sukses.

Sementara itu, pelajaran olahraga pada usia enam sampai empat nelas tahun, mesti disesuaikan dengan tingkatan usia murid. Porsi dan jenis olahraga yang diajarkan untuk anak usia enam tahun boleh jadi berbeda degan anak yang usianya telah mencapai empat belas tahun.Oleh sebab itu, guru mesti memahami secara baik kondisi fisik murid.

\section{c. Usia 14 Tahun ke Atas}

Menurut Ibnu Sina, pada usia empat belas tahun ke atas, murid mesti memperoleh mata pelajaran yang berbeda dari tingkatan usia sebelumnya. Dalam hal ini, mata pelajaran mesti dirumuskan berdasarkan pertimbangan minat dan bakat murid. Murid juga bisa diarahkan untuk berfokus pada penguasaan bidang ilmu tertentu.

Dalam konteks inilah, mata pelajaran untuk anak usia empat belas tahun ke atas dapat dibedakan ke dalam dua kelompok, yaitu mata pelajaran yang bersifat teoritis dan praktis. Pembagian ini di pengaruhi oleh pemikiran Aristoteles. Tetapi, Ibnu Sina menambahkan ilmu-ilmu lain ke dalam kelompok ilmu yang bersifat teoritis dan praktis yang didasarkan pada ajaran agama Islam.

Menurut Ibnu Sina, di antara mata pelajaran atau disiplin ilmu yang bersifat teoritis ialah ilmu fisika, biologi, kedokteran, astrologi, kimia, 
matematika, dan ilmu ketuhanan. Sementara, di antara disiplin ilmu yang bersifat praktis ialah ilmu akhlak, muamalah, pendidikan, syariat, dan ilmu politik. Dalam hal ini, jelas bagi kita bawha Ibnu Sina telah berhasil menggagas format pendidikan nondikotomik. Ketika berbicara tentang ilmu-ilmu yang bersifat praktis tersebut, Ibnu Sina mengaitkannya dengan berbagai tugas dan pekerjaan yang ada adalam kehidupan sehari-hari, baik dalam konteks kehidupan rumah tangga, masyarakat, maupun dunia kerja. Dengan ilmu yang bersifat praktis, murid mampu memperoleh pekerjaan yang layak untuk menghidupi diri dan keluarganya.

\section{B. Metode Pembelajaran yang Efektif}

Dalam setiap pembahasan materi pelajaran, Ibnu Sina senantiasa berbicara mengenai cara mengajarkannya kepada murid. Ia menyatakan bahwa guru tidak akan mampu menjelaskan suatu materi kepada murid yang bermacam-macam hanya dengan mengandalkan satu cara atau metode. Oleh sebab itu, penyampaian materi tersebut, supaya metode dan materi yang diajarkan memiliki daya relevansi. Adapun penjelasasn lengkap ihwal ragam metode pembelajaran tersebut ialah sebagaiberikut : ${ }^{16}$

\section{a. Metode Talqin}

Metode Talqin adalah metode belajar dengan memberikan contoh. Metode ini relevan digunakan untuk mnegajarkan mata pelajaran membaca al-Qur'an. Metode ini dimulai dengan cara memperdengarkan bacaan hafalan al-Qur'an kepada murid, sedikitndemi sedikit. Kemudian, murid diminta untuk mendengarkan dan mengulangi bacaan tersebut secara perlahan-lahan. Kemudian, dilakukan secara berulang-ulang sampai murid hafal.

Menurut Ibnu Sina, metode talqin dapat pula ditempuh dengan cara seorang guru meminta bantuan kepada murid yang sudah ahli untuk membimbing teman-temannya yang masih tertinggal. Cara seperti ini dalam ilmu pendidikan modern dikenal dengan istilah tutor sebaya. Dengan demikian, dapatlah dikatakan bahwa pemikiran Ibnu Sina tentang metode talqin sejatinya telah melampaui zaman.

\section{b. Metode Demonstrasi}

Metode demonstrasi adalah metode mengajar dengan cara mepergunakan barang, kejaadian, aturan, dan urutan melakukan kegiatan, baik secara langsung maupun melalui penggunaan media pengajaran yang relevan dengan pokok bahasan atau materi yang sedang disajikan. Metode ini digunakan agar teori yang dipelajari langsung bisa diaplikasikan sehingga tidak terjadi kesalahan dalam memahamai sesuatu.

Metode demonstrasi dapat digunakan dalam pembelajaran yang bersifat praktik, seperti menulis, membaca atau menghafal al-Qur'an, qira'ah, menyanyi,

${ }^{16}$ Ibid., hlm.132-137. 
memasak, menjahit, merias, teknik bangunan, pertukungan, praktik shalat, manasik haji, dan sebagianya. Metide ini ditempuh agar praktik di lapangan yang sebenarnya nanti mempeoleh hasil yang memuaskan, sebab murid telah memiliki pengetahuan dasar dan pengalaman untuk mendemondtrasikan teori yang telah dipelajarainya.

Menurut Ibu Sina, apabila menggunakan metode demosntrasi, misalnya untuk mengajar menulis, maka ia terlebih dahulu mesti mecontohkan tulisan hijaiah di hadapan para murid. Setelah itu, barulah guru meminta mereka untuk mendengarkan ucapan huruf-huruf hijaiah sesuai dengan makhraj-nya dan dilanjutkan dengan mendemonstrasikan cara menulisnya.

\section{c. Metode Pembiasaan dan Teladan}

Metode pembiasaan dan teladan merupakan metode yang paling umum digunakan guru untuk mengajar, membina, dan membimbing murid. Ibnu Sina menyatakan bahwa pembiasaan termasuk metode pengajaran yang palig efektif, khususnya dalam mengajarkan akhlak. Metode ini tentu saja mesti disesuaikan dengan perkembangan jiwa murid agar mencapai hasil yang maksimal.

Penting untuk diketahui, inti dari pembiasan ialah perulangan terhadap segala sesuatu yang dilaksanakan atau yang diucapkan oleh seseorang. Hampir semua ahli pendidikan sepakat bahwa pembiasaan merupakan metode pendidikan yang jitu, sebab metode ini akan mengarahkan murid untuk membiasakan diri terhadap suatu hal yang baik.

\section{d. Metode diskusi}

Metode diksusi adalah suatu kegiatan kelompok dalam memecahkan persoalan untuk mengambil suatu kesimpulan. Tentunya, diskusi tidaklah sama dengan berdebat. Sebab, disksusi senantiasa diarahkan kepada pemecahan masalah (problem solving) yang menimbulkan berbagai pendapay dan akhimya diambil suatu kesimpulan yang dapat diterima oleh anggota dalam kemompoknya.

Dengan kata lain, metode diskusi merupakan metode mengajar yang sangat kaitannya dengan belajar memecahkan masalah. Metode ini lazim disebut sebagai diskusi kelompok dan resitasi bersama. Sebab, diskusi senantiasa dilakukaan oleh lebih dari satu orang. Metode ini dimaksudkan untuk merangsang pemikiran dan kreativitas murid. Pasalnya, murid diajak untuk berani mengemukakan pemikirannya di hadapan teman-temannya.

\section{e. Metode magang}

Metode magang merupakan metode pembelajaran yang umum digunakan oleh para ulama dalam mendidik, mengajar, dan membimbing murid. Metode ini melibatkan murid secara langsung untuk berhadap-hadapan dengan realitas lapangan kajian atau penelitian setelah mereka belajar tentang beragam teori keilmuwan. Metode ini biasanya dilakukan dalam waktu yang tidak singkat. Berkenaan dengan metode magang, Ibnu Sina telah menggunakan metode ini dalam kegiatan pengajaran yang dilakuakanya. Para murid Ibnu Sina yang mempelajari ilmu kedokteran, biasanya dianjurkan agar menggabungkan teori dan 
praktik. Pada suatu waktu, murid mempelajari teori di kelas. Lalu, pada waktu yang lain, murid mempraktikan teori tersebut di rumah sakit atau balai kesehatan.

Menurut Ibnu Sina, metode magang apabila digunakan secara tepat niscaya akan menimbulkan manfaat ganda. Pertama, metode ini akan menjadikan murid lebih mahir dalam suartu bidang keilmuwan. Kedua, metode ini akan mendatangkan keahlian dalam bekerja yang menghasilkan kesejahteraan secara ekonomis bagi murid.

\section{f. Metode penugasan}

Metode penugasan merupakan penyajian tugas yang diberikan oleh pendidik. Masalah tugas yang dilaksanakan peserta didik dapat melakukanya dimana saja, baik itu disekolah atau tempat belajar lainnya. Metode ini biasanya diberikan karena bahan pelajaran terlalu banyak, sementara waktunya sedikit.

Tugas tentunya tidak sama dengan pekerjaan tumah (PR). Cakupan tugas jauh lebih luas dari PR. Bahkan, sering kali dikakatan bawha PR termasuk bagian dari tugas .Pemberian tugas oleh guru kepada para murid dimaksudkan untuk merangsang daya kreatif dan memotivasi semangat belajar aktif pada diri mereka, baik dalam bentuk kelompok maupun individu. Oleh sebab itu, tugas dapat diberikan secara individu atau kelompok.

Berkaitan dengan penugasan, Ibnu Sina dalam praktik mengajarnya sering kali menggunakan metode tersebut. Biasanya, ia akan menyusun sejumlah modul atau naskah, yang kemudian ia kirimkan kepada para muridnya untuk dipelajari. Cara ini, misalnya, pernah ia lakukan terhadap beberapa muridnya, seprerti Abu ar-Raihan al-Bairuni dan Abi Husain Ahmad as-Suhaili.

\section{Konsep Guru Ideal}

Ibnu Sina termasuk seorang pakar pendidikan yang secara serius menyoroti persoalan pendidikan, di antaranya tentang konsep guru ideal. Maksud dari guru ideal di sini ialah guru yang baik dan profesional dalam menjalankan tugas dan tanggung jawabnya sebagai tenaga pendidikan. Dengan kata lain, ia merupakan sosok yang memahami tugas dan fungsinya sebagai guru secara baik.

Kriteria guru yang ideal menurut Ibnu Sina ialah guru yang memiliki kecerdasan, memeluk agama Islam, mengetahui cara membina akhlak, piawai dalam mendidik, berpenampila tenang dan menarik, tidak gemar mengolok-olok dan bermain-main di hadapan murid, tidak bermuka masam, bersikap sopan dan santun, serta memiliki hati yang bersih suci, dan murni.

Ibnu Sina menambahkan bahwa seorang guru yang ideal itu sebaiknya dari kaum pria yamg terhormat dan menonjol budi pekertinya, cerdas, teliti, sabar, dan telaten dalam membimbing murid. Selain itu, ia mesti mampu bersikap adil terhadap seluruh murid, berdisiplin dalam penggunaan waktu, gemar bergaul dengan murid, tidak keras hati, serta selalau menghias diri dengan akhlak mulia. Dengan konsep guru ideal sebagimana dirumuskan oleh Ibnu Sina tersebut, nisacaya seorang guru akan mampu mencerdaskan muridnya dengan beragai ilmu 
pengetahuan. Bakan, ia akan mampu membekali muridnya dengan kepribadian atau akhlak yang mulia. Alhasil, konsep guru ideal tersebut relevan dengan jaranajaran pokok Islam yang menekankan pentingnya integrasi antara aspek kelmuwan dan aspek moral atau akhlak sehingga melahirkan konsep manusia sempurna (insan kamil) ${ }^{17}$

\section{Konsep Hukuman Edukatif}

Pada dasarnya, mengenai konsep hukuman (punishment) dalam proses pembelajaran, Ibnu sina, sebagimana disumpulkan oleh Abudin Nata yang di kutip oleh Yanuar Arifin, tampak tidak mendukung penggunaan hukumman. Hal ini ia dasarkan pada skapnya yang senantiasa menjunjung tinggi harkat dan martabat manusia. Tetapi, dalam praktiknya, ia membolehkan adanya hukuman untuk murid. Dengan cacatan, hukuman diberikan hanya dalam kondisi terpaksa dan dilakukan secara berhati-hati.

Sementara itu, dalam kondisi normal tidak boleh digunakan oleh guru untuk mendisiplinkan muridnya. Guru mesti mengedepankan hadiah daripada hukuman. Sebab, pemberian hadiah atau populer dengan istilah reward sehubungan dengan alam demokrasi yang menuntut adanya keadilan, kamanusiaan, dan kesetaraan. Dengan kata lain, guru mesti mampu memanusiakan murid sebagai objek dan subjek belajar.

Menurut Ibnu Sina sebagaimana yang disimpulkan oleh Ali al-Jumbulati, mengatakan bahwa dalam melakukan hukuman terhadap murid, sebaiknya diberikan peringatan dan ancaman terlebih dahulu. Guru sebaiknya tidak mengambil tindakan tehadap muroid dengan kekerasan, tetapi dengan kelembutan hati. Lalu, murid diberi motivasi dan persuasi, baik dengan tampilan muka masam atau dengan puji-pujian. Dengan begitu, murid akan mendorong melakukan kebaikan.

Dari uarain tersebut, jelaslah bagi kita bahwa Ibnu Sina sebenar-benarnya tidak memperbolehkan adanya hukuman. Namun, hukuman dapat diberikan dalam keadaan terpaksa, tetapi dengan cara yang sangat berhati-hati. Jadi, konsep hukuman Ibnu Sina ialah hukuman edukatif, sebab sifatnya tidak boleh menyakiti fisik dan psikis murid. Konsep hukuman ini relevan dengan konsep hukuman yang ditawarkan para pakar pendidikan kontempore, yakni berdasarkan pertimbangan psikologi atau mertabat manusia.

\section{E. Relevansi Pemikiran Pendidikan Ibnu Sina di era modern}

Relevansi pendidikan perspektif Ibnu Sina dapat dikatakan sangat relevan di era modern ini, karena sesuai dengan UU No 20 Tahun 2003 menegnai sistem dan tujuan pendidikan nasional. Berdasarkan hal tersebut konsep pendidikan perspektif ibnu sina sangat relevan apabila masih diaplikasikan di zaman sekarang. Karena, pendidikan yang diaplikasikan ibnu sina sbagian besar sesuai

${ }^{17}$ Ibid., hlm. 137-138 
dengan kebutuhan sekarang, sebahagian di lembaga-lembaga pendidikan saat ini, masih banyak menggunakan model pendidikan seperti yang diaplikasikan oleh Ibn Sina, mulai dari strategi, metode dan tujuan pendidikannya sampai kriteria seorang guru yang diharapkan dalam pendidikan Islam. Dengan konsep pendidikan yang di implementasikan oleh Ibnu Sina benar-benar untuk mengupayakan peningkatan mutu pendidikan Islam.

Adapun konsep yang ditawarkan oleh ibnu sina sangat masih relevan diterapkan pada zaman ini, seperti dalam penyusunan kurikulum hendaknya mempertimbangkan aspek psikologis anak. Kurikulum yang hendak diterapkan harus sesuai dengan potensi anak dan harus seimbang antara jasmani, intelektual, dan akhlaknya. Usia dini, pendidikan akhlak harus lebih ditekankan. Pada usia remaja diseimbangkan antara afektif, psikomotor dan kognitif.

Ibnu sina menwarkan kurikulum pragmatisme-funsional, yakni dengan melihat segi kegunaan dari ilmu dan keterampilan yang dipelajari sesuai dengan tuntutan masyarakat, dan tunttuan perkembangan zaman atau berorientasi pasar (marketing oriented). Kemudian kurikulum harus berlandaskan kepada ajaran dasar dalam Islam, yaitu al-Qur'an dan Sunnah sehingga anak didik akan memiliki iman, ilmu, dan amal secara integral. Kurikulum yang ditawarkan Ibnu Sina berbasis akhlak dan bercorak integralistik dan mencakup pendidikan seni dan syair yang merupakan bukti bahwa Ibnu Sina memberikan perhatian yang serius terhadap pendidikan akhlak.

Mengenai metode dalam perspektif Ibnu Sina menwarkan empat karateristik: pertama, penyesuaian metode yang akkan diberikan harus disesuakan dengan karakteristik materi ajar. Kedua, metode yang hyang ingin diterapkan harus mempertimbangkan psikologis peserta didik, termasuk pada minat dan bakatnya. Ketiga, metode yang diberikan tidak kaku, melainkan dapat mengubah sesuai situasi dan kebutuhan peserta didik. Keempat, harus memiliki kecerdasan dalam menetapkan kesesuaian dan ketepatan metode, ini merupakan salah satu keberhasilan belajar. ${ }^{18}$

Dari beberapa karakter yang ditawarkan Ibnu Sina masih relevan dengan perkembangan dan tuntunan zaman saat ini. Jadi, ini merupakan Ibnu sina memang memahami konsep pendidikan, baik itu secara praktis maupun teoritis sehingga pesrpektif pendidikan yang dikemukakannya tidak hanya berlaku pada masanya saja, tetapi lebih dari itu yakni melampaui masanya tersebut. Sehingga tetap fleksibel sesuai dengan perkembangan dan kebutuhan zaman.

\section{Kesimpulan}

${ }^{18}$ Miftaku Rahman, "KONSEP PENDIDIKAN ISLAM MENURUT IBN SINA DAN RELEVANSINYA DENGAN PENDIDIKAN MODERN | Rohman | Epistemé: Jurnal Pengembangan Ilmu Keislaman,” diakses 3 April 2020, http://103.106.116.16/index.php/epis/article/view/47. 
Dari hasil penjelasan perpektif pendidikan diatas, bahwa menurut Ibnu Sina pendidikan diarahkan pada potensi dan didasarkan dengan strategi, metode, kurikulum yang baik. Dengan tujuan, potensi seseorang tumbuh dan akan berkembang sesuai dengan bagaimana kita mengajarkan pendidikan yang diberikan. Ia mengungkapkan bahwa karakter manusia tumbuh dan berkembang bila bagaimana kita memberikan pendidikan yang sesuai dengan potensi-potensi peserta didik. Ibnu sina memandang bahwa pendidikan sebagai sarana untuk menjadikan peserta didik mulia dan berbudi pekerti luhur bukan hanya sekedar pada pengetahuanya.

\section{Daftar Pustaka}

Abdul Majid, Dian Andayani. Pendidikan Karakter Perspektif Islam. Bandung: PT. Remaja Rosdakarya, 2017.

Armai Arief. Pengantar Ilmu dan Metodologi Pendidikan Islam. Jakarta: Ciputat pers, 2002.

Ibn Miskawaih. Menuju Kesempurnaan Akhlak Terjemahan dari Tahdjib AlAkhlak Karya Abu Ali Ahmad Ibn Miskawaih. Bandung: Mizan, 1994.

Miftaku Rahman. "KONSEP PENDIDIKAN ISLAM MENURUT IBN SINA DAN RELEVANSINYA DENGAN PENDIDIKAN MODERN | Rohman | Epistemé: Jurnal Pengembangan Ilmu Keislaman.” Diakses 3 April 2020. http://103.106.116.16/index.php/epis/article/view/47.

Nana Syaodih Sukmadhinata. Metode Penelitian Pendidikan. Bandung: PT. Remaja Rosdakarya, 2012.

Prof. Mulyasa. Pengembangan dan Implementasi Kurikulum 2013. Bandung: PT. Remaja Rosdakarya, 2013.

Ramayulis. Ilmu Pendidikan Islam. Jakarta: Kalam Mulia, 2002.

Sirajuddin Zar. Filsafat Islam filosof dan filsafatnya. Jakarta: PT. Raja Grafindo Parsada, 2012.

Slameto. Proses Belajar Mengajar Dalam Sistem Kredit Smester. Jakarta: Bumi Aksara, 1991.

Sutrisno dan Suyatno. Pendidikan Islam Di Era Peradaban Modern. Jakarta: Kencana, 2015.

Suwardi dkk. Panduan Penulisan Skripsi. Yogyakarta: FITK UIN Sunan Kalijaga, 2012.

Syarkawi. Pembentukan Kepribadian Anak. Jakarta: Bumi Aksara, 2011.

Syarnubi, Syarnubi. "PROFESIONALISME GURU PENDIDIKAN AGAMA ISLAM DALAM MEMBENTUK RELIGIUSITAS SISWA KELAS IV DI SDN 2 PENGARAYAN." Tadrib 5, no. 1 (1 Juli 2019): 87-103. https://doi.org/10.19109/tadrib.v5i1.3230.

Yanuar Arifin. Pemikiran-Pemikiran Emas Para Tokoh Pendidikan Islam dari Klasik hingga Modern. Yogyakarta: Lintang Pusataka Utama, 2017.

Zakiah Drajat dkk. Ilmu Pendidikan Islam. Jakarta: Bumi Aksara, 2012. 